Article

\title{
The Role of Public Governance in the Pursuit of Sustainable Development of the ILVA Steel Plant: An Interpretative Framework
}

\author{
Mario Turco ${ }^{1}$ and Rossella Leopizzi ${ }^{2, *}$ \\ 1 Department of Economic Sciences, University of Salento, 73100 Lecce, Italy; mario.turco@unisalento.it \\ 2 Ionic Department Ionic Department in Legal and Economic System of Mediterranean: Society, Environment, \\ Culture, University of Bari, 74100 Taranto, Italy \\ * Correspondence: rossella.leopizzi@uniba.it
}

Received: 10 September 2020; Accepted: 5 October 2020; Published: 8 October 2020

\begin{abstract}
The aim of this paper was to investigate the role of public institutions in the pursuit of sustainable development in a case study of international relevance: Taranto's ILVA steel plant, which is one of the biggest steel and iron centres in Europe. The case study was analysed through investigating the different aspects of sustainable development in the four phases of development of the steel plant, from public direct management to private management. The analysis, based on a series of unstructured data, was carried out by applying a triple bottom line approach and the total interpretative structuring model (TISM). Evidence shows how-in the absence of stable, coherent, strong and present public institutions, capable of reading the forces of the local and international context and of intervening with regulatory actions inspired by a planned and interiorized economic strategy - the market, left in the hands of the private entrepreneur only, is destined to fail, and the paths of multidimensional sustainable development stray away from the ambitions of modern states.
\end{abstract}

Keywords: sustainable development; ILVA steel plant; role of public governance

\section{Introduction}

In the current scientific debate, more and more significance is given to the concept of "sustainable development" and to its pursuit by enterprises, public institutions, and civil society in a broad sense. In particular, the relevance of this topic is recognized by the United Nations, who, with the definition of the 17 sustainable development goals to be achieved by 2030, demand the commitment of every acceding country in the definition of their own sustainable development strategy, which should allow reaching the goals by the deadlines set by the 2030 Agenda [1].

Against this background, after having analysed the main paradigms formulated by the economic literature with regards to the different types of intervention of public institutions in the sustainment of growth and economic development, this article investigates the role assumed by the institutions in the pursuit of sustainable development through the analysis of a case study.

Specifically, Taranto's ILVA, one of the biggest steel and iron centres in Europe, has developed across different phases in which the state has directly managed the plant and then privatized it. This research identified and investigated four phases of development: the initial one, in which the plant was established and publicly managed; the period of privatization in the second half of the 1990s; the phase of receivership and extraordinary management; and the current phase, with the new private management assigned to the multinational ArcelorMittal, a world leading company in the sector, which, incidentally, boasts—at least on paper-a pro-active approach and long experience with social responsibility and sustainable development. 
For each of the aforementioned phases, this study analysed the features that have characterized their governance mechanisms, observed within the frame of sustainable development, in line with the main theoretical frameworks developed on an international level.

To analyse the role of public institutions in the pursuit of sustainable development-or lack of thereof-in line with previous and well-established studies [2-5], this study used a longitudinal qualitative analysis for the ILVA case, investigating the different aspects of sustainable development in the aforementioned historical phases. This analysis, of an inductive type, is based on a series of unstructured data such as newspapers, interviews and blogs and national, European, and regional legal sources. The analysis of these data allowed us to reconstruct and interpret the events, identifying the relevant aspects.

Starting from these considerations, the present work analysed the case of Taranto's ILVA and had the goal of investigating the role of the state in the composition of the sustainability dimensions over time, and of verifying the guidelines with which the Italian government has decided to orient its governance choices in order to achieve the broader national development goal. The main innovation brought by this analysis resides in the fact that it tackled, through an empirical study, how the aim of social and national convenience pushes the political governance to accept corporate and local socio-environmental non-sustainability, implementing intervention mechanisms that combine and orient various interests.

The complexity of the situation; the economic, environmental and social tradeoffs of the present case study; and the large numbers of stakeholders involved make the ILVA case a particularly interesting scenario for the discussion of a sustainable business model [6].

The contribution of this paper is to suggest that a more comprehensive assessment of sustainability considerations might be better integrated into business model evolution in order to achieve sustainable development. On the contrary, if the Italian government operates outside of a well-aware, mature and shared industrial strategy and through actions dictated by the emergence of a situation, the failure of the market and attempts to regulate it are inevitable.

\section{Theoretical Framework}

Focusing on the different roles played by the state in the composition of the numerous and often-clashing interests in the field and thus on the intensity and the modalities of intervention in the market mechanisms, economic literature has followed two main trajectories: one of an interventionist and regulatory nature, typical of the 19th and 20th century, and the other of a composite nature, developed in the last two decades of the 20th century together with the evolution and progressive opening of markets.

The interventionist state model [7-11] is characterized by the massive presence of the state in the economy and by a high number of public interventions. Eloquent symbols of this approach are represented, for instance, by banking law (R.D. March 12th 1936, n. 375), by trade law, by the foundation of the Istituto Mobiliare Italiano (IMI, "Italian Mobiliar Institute") as an attempt to rearrange the Italian banking system, and by the establishment of the Istituto per la Ricostruzione Industriale (IRI, "Institute for the Industrial Reconstruction"). Likewise, pursuant to the Constitutional Law of 1948, in the 1950s, the number of state interventions both in the economic and social spheres progressively increased, leading to the so-called "welfare state", mainly based on wealth redistribution policies. Within this paradigm, the role of the state as a businessman consolidates itself, that is, the state that manages, often in a monopoly regime, economic activities that produce goods and services through public enterprises existing in different sectors of the economy. The public function, which within the formal state has functions and boundaries that can be easily distinguished from the entrepreneurial private one, thus begins integrating and substituting the reality of enterprises, to later become its competitor. From the welfare state phase, therefore, we enter into what could be defined as the "service state", in which the public entities are extensively involved in the direct production of services. In Italy, this translates into a progressive rationalization of the state participation system, with the establishment 
of the Ministry of State Participations and of the Interministerial Committees for Industrial Production (CIPI) and for Economic Planning (CIPE), on which depended the management bodies for state participation (IRI, ENI and EFIM), which, in turn, controlled—through subholding - the galaxy of companies operating in all sorts of sectors.

However, these approaches have been strongly criticized over the years, because of the fact that international competition and the resulting need for stronger production efficiency required a more-careful selection of public intervention areas and more-limited state intervention in the entrepreneurial economic sphere involving those types of goods and services that society or the market system cannot guarantee according to civil, social and ethical principles existing in a particular community. Consequently, this implied withdrawal from all areas in which public intervention could bring the establishment of oligopolies and unfair competition against other social and economic subjects [12].

In addition, during the 1980s, with the increase in public expenses that had perpetuated the economic crisis, a discussion arose about the interventionist role of the state that especially characterized the Italian economic reality, whose economic policies to support enterprises in crisis were mostly based on the use of public resources to periodically pay off their structural losses, through the instrument of regulatory actions designed to recapitalize the endowment funds of the management bodies of state participations. At the same time, in the Anglo-Saxon countries, and gradually in Europe, there followed a reconsideration of the neoliberal paradigms that gave back to the market system and to its self-regulation mechanisms a central role in national economies. Hence, between the 1980s and the 1990s, on the heels of the Anglo-Saxon experience and under the influence of European law, the "regulatory state" arrived in Italy too, and it has represented the dominant paradigm of the last twenty years [13].

Regulation theory recognizes the centrality of institutions in economic life, offering a heterodox view of capitalist development [14-16]. The advocates of this approach think that the role of and the control exercised by the state should be of indirect types and must consist of the regulation of the activity exercised by third parties in the market, through the definition of standard and pseudo contracts [17]. Thus, the phases of stability and the processes of growth and capitalist accumulation in the long run have to be supported, beyond the inherent, unavoidable imbalances and distortions, and the social mechanisms of regulation-understood as the system of rules, customs and ideologies that characterize the socio-economic structure of the state, and which define and make possible and coherent the model of accumulation. In hindsight, the reference is to that system of "compromises" that make the processes of accumulation compliant with the social cohesion of a determined territorial context. From this perspective, the public institutions that are part of the regulation system mediate and compose the emerging social contradictions in a dynamic way, with the aim of reducing them to simple differences, through mechanisms and instruments of normalization, mediation and regulation. In other words, it is about achieving a balanced and sustainable combination, in a dynamic way, of accumulation processes and regulation instruments, which is not easy to achieve if the complexity and diversity of the socio-economic relations of each local context are taken into consideration. The primary function of the state, thus, is to put in place the appropriate instruments to make the strategies of economic policy more coherent and sustainable regarding the social demands of justice and equity, finding a distribution of costs and benefits tied to growth that can be considered acceptable for each stakeholder [18].

This approach has had different evolutions with the introduction of the environmental variable in the model of interactions that the regulatory state has to compose and mediate in order to ensure sustainability in the long run of the processes of growth and the quality of capitalist development [18-22]. Indeed, the perdurability of the processes of wealth accumulation cannot be separated from the consideration of the environmental issues, which, on par with social issues, manifest themselves predominantly with the divergent logic between the short-term interest of economic activity and the long-term interest of environmental sustainability [23]. 
In line with the currents described above, taking into consideration the significant role that the concept of sustainable development has acquired over time, on the levels both of national politics and of individual enterprises, and, above all, following the introduction of the 17 sustainable development goals set by the United Nations in the 2030 Agenda, this paper focuses on the type of intervention of the state, from the perspective of pursuing sustainable development, in the nationally relevant case of the ILVA steel plant in Taranto.

\section{Methodology}

In order to analyse the role of the state in the pursuit (or lack of thereof) of sustainable development in the ILVA case, the four historical phases of development of the steel plant were identified, and an analysis making use of the triple bottom line approach [24] and of total interpretative structural modelling (TISM) were conducted on each of those [25]. TISM is a method that helps to convert ill-structured mental models into well-articulated models that act as the basis for conceptualization and theory building [26]. The application of TISM can be extended to articulate and interpret [27] many more complex issues in decision making and culture and policy formulation. Two important factors from each section of the triple bottom line are used. Hence, a total of six important factors are taken for the model (Figure 1 and Table 1). Factors such as sustained economic growth and shareholder value are taken from the economic perspective; similarly, the standard of living of neighbourhoods and human rights of employees are taken from the social perspective; the level of pollution and the reduction of emissions are taken from the environmental perspective.

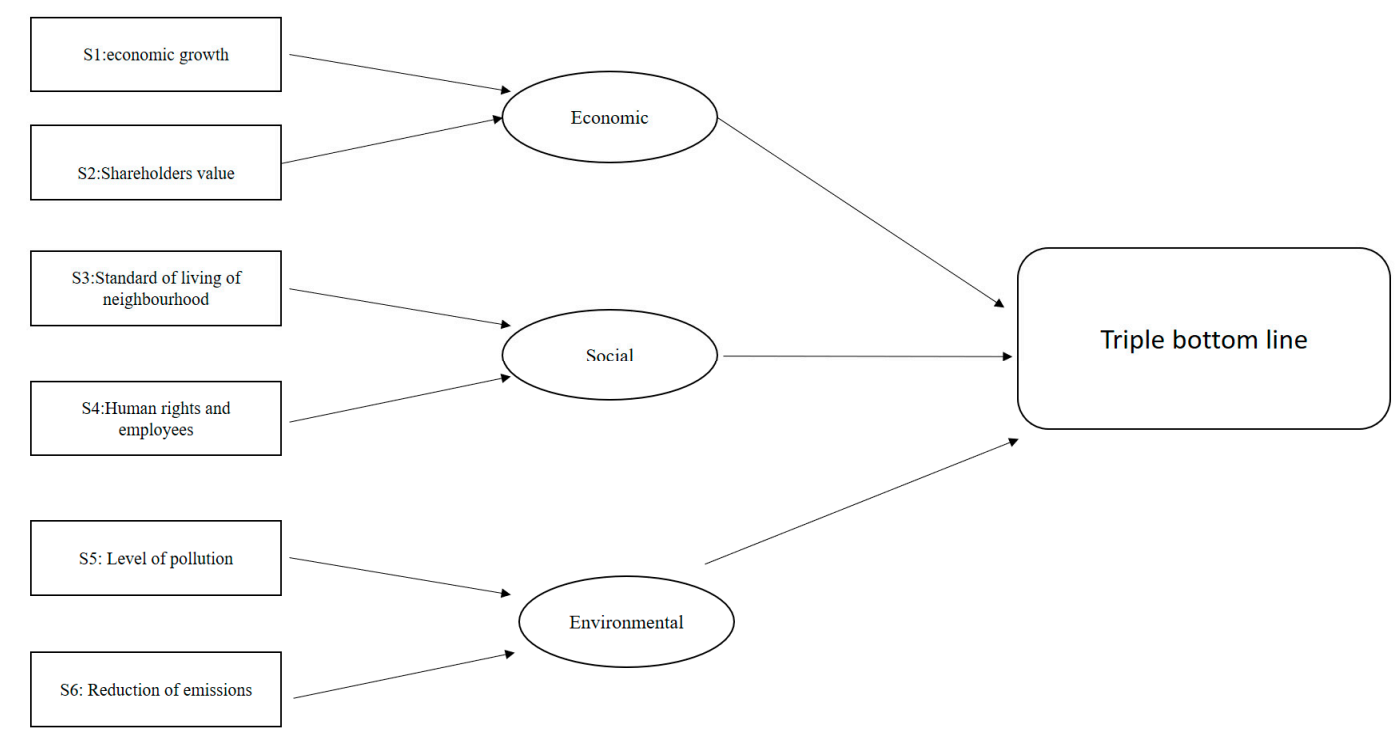

Figure 1. The application of TISM.

Table 1. The application of TISM

\begin{tabular}{ccc}
\hline Code & Description & Perspective \\
\hline S1 & Sustained economic growth & Economic \\
S2 & Shareholder value & Economic \\
S3 & Standard of living of & Social \\
S4 & neighbourhood & Social \\
S5 & Human rights and employees & Environmental \\
S6 & Level of pollution & Environmental \\
\hline
\end{tabular}


The Total Interpretative Structural Model is performed as a stepwise process. The TISM methodology was applied for this study. Data and information were taken from newspapers, blogs, social media, reports and other unstructured data [28], typical of qualitative analysis [5,29]. In fact, it should be noted that the ILVA case is more of a legal and political-economic topic than a subject of academic research. Consequently, most of the sources used are not academic texts but general media articles as well as legal decisions taken by various actors.

\section{Background to Case}

The ILVA steel plant in Taranto was built within a broader economic policy project aimed at the achievement of two goals: the revitalisation of Southern Italy and, above all, the pursuit of the strategic and economic national interest of creating an iron and steel plant that could boost Italian heavy industry and become its flagship in the run for international markets, following the growing demand for steel registered on national and international levels [30-33].

It follows that, as a consequence of the approval of the Committee of Ministries for Southern Italy, in 1960 in Taranto, work began on the construction of the fourth Italian integrated steelworks plant, under the guidance of two of the biggest Finsider companies, Ilva and Cornigliano, which merged together in 1961, creating the ITALSIDER.

The steel plant cost almost four hundred billion Lira (ITL) (the old Italian currency before the introduction of the Euro) and took up, first, 600 and, later, 1500 hectares of surface, with a total extent equal to twice the whole city. On the surface stood five blast furnaces taller than $40 \mathrm{~m}$ and with a diameter of 10-15 m, conveyor belts stretched for $190 \mathrm{~km}$, streets for $50 \mathrm{~km}$, and railways for $200 \mathrm{~km}$. With its eight mineral parks, two quarries, 10 batteries to produce coke, five blast furnaces, five continuous castings, two hot rolling mills for strips, a hot rolling mill for sheet metal, a cold rolling mill, three galvanizing lines and three pipes [34], originally, ITALSIDER could produce 3 million tons of steel per year. This production capacity increased to 4.5 million in 1970, with 4500 employees, and to 11.5 million in 1975, with 43,000 employees, in 1981 (the so-called. Il raddoppio, "the doubling").

The choice to establish the plant in the Ionian city was tied to a series of factors, first and foremost, the engineering and mechanic tradition connected to the naval industry, and the widespread belief that localizing a steel plant in Taranto would have represented, even in the short run, the best sort of investment to promote the positive effects of economic development, upstream and downstream, partly owing to the cheap location $[35,36]$. Furthermore, placing an integrated steelwork plant in a coastal town right in the middle of the Mediterranean Sea would have resulted in an easier provision of raw materials from overseas countries and, especially, an easier export of finished and semi-finished products, the primary goal of the expansionary economic policies of the time. Finally, choosing Taranto represented some specific political decisions of governance related to the need to revitalize Southern Italy and to answering to the socio-economic needs of the local community [6].

During the mid-1990s, following the period of international crisis in which the iron and steel industry was, the IRI-within a broader process of disinvestment and privatization-decided to transfer the property of Taranto's steel plant to the Riva group for ITL 1460 billion [37].

In the same years, concurrently with the crisis faced by the global steel industry and the increase in the attention reserved for environmental matters, Taranto and the surrounding area corresponding to the municipalities of Statte, Massafra, Montemesola and Crispiano were defined by the Ministry of the Environment as a "high environmental risk area" [38].

In the 2000s, the Community legislation, inspired by a logic of "sustainable development" and the growing sensitivity towards environmental issues, brought a shift in focus towards the problem of the dangerous dioxin and benzo(a)pyrene emissions into the atmosphere from the ILVA plant [6]. In this period, the public opinion changed regarding consideration of the presence/consequences of the steel plant in Taranto. The period of public approval for economic and social reasons was to be short lived.

This ongoing change in values manifested itself on the local administration level in 2008, when the newly elected Regional Council approved the so-called anti-dioxin law, which, besides setting stricter 
boundaries for atmospheric emissions generated by production facilities operating in the metallurgical sector, ruled the closure of the plant in the case of exceeding the allowed limits.

In 2012, Taranto's judiciary—on the basis of the report issued by the Ecological Operational Unit (NOE) and two assessment reports (a chemical one and an epidemiological one)-impounded the plant for severe environmental violations and ruled supervision measures for some of the suspects in the inquiry into an environmental disaster.

Indeed, these measures ruled by the judiciary were followed by many different depositions by experts, top management of the company and ministers in front of parliamentary and governmental committees, who tackled this tricky matter keeping in mind the sustainability challenges that resulted from it, including economic, health, environmental and unemployment risks. These institutional round tables led to measures contrasting with the judiciary's decision; in fact, in October 2012, the Ministry of Environment issued a decree containing provisions to guarantee economic recovery and continuity, with the proviso that early intervention measures had to be enacted on the hot-working machinery (Decree of the Ministry of the Environment, 27 October 2012).

In turn, the judiciary, blatantly in conflict with this governmental provision, impounded the plant in November 2012. Governmental institutions replied to this action on 3 December 2012 with another Decree-Law, which defined ILVA S.p.A. as a "site of national interest" (S.I.N.), thus guaranteeing the continuation of production for a period not longer than 36 months with the application of the requirements set by A.I.A.

Subsequently, on the 5th of December 2012, the public prosecutor's office adopted another measure that established that the impounded plants should have been returned to the Rivas. Finally, on Christmas Eve 2012, the Salva ILVA ("save ILVA") decree became law, prevailing over the previous judiciary decision (Law n. 231/2012). The tug of war between the judiciary and the governmental political institutions culminated in May 2013, when the judge for the preliminary investigations, Patrizia Todisco, issued the order to seize EUR 8 billion in property and bank deposits of the Riva group. However, this provision was cancelled at the end of the same year by the Cassation Court after the Rivas appealed. A few days after the verdict, the Rivas left the administration of the company; thus, public governance had to step in, first with commissioner management and then with special administration, in order to guarantee the continuity of production activities [39].

In the interim period set in the contract award notice for the submission of tenders, in order to cover the losses of the semester, estimated at EUR 50 million a month, the government authorities issued a new Salva ILVA decree. It foresaw a budget of around EUR 300 million for the extraordinary administration, which would then be returned within 60 days from the date on which the final transfer of the ILVA company would take place, so as to avoid community censorship related to the discipline of state aid. This represents another clear signal of interventionist policies, even if applied without the guiding principle of shared knowledge that inspires the intervention lines put in place by the public governance in order to safeguard national economic-productive interests, even in the presence of newly enlightened European interests, divergent and opposed to the Italian ones, and of environmentalist pressures.

Regarding the call for tenders, it is stated that, with the D.L. 191/2015, commissioners are expected to propose supplementary measures before the deadline for the implementation of the environmental plan, which is set on the 23rd of August 2023. This translates into benefits for the future buyers of the ILVA plant, which, in their official purchase proposal, will be able to state only the environmental interventions they will perform with their own resources, while the others will be reserved for the extraordinary administration and paid for with the assets seized from the Rivas. In order to achieve this goal, by means of the following D.L. 243/2016, it was established that the extraordinary administration would temporarily continue to exist in parallel with the private management, for the purpose of carrying out environmental rehabilitation, which would be administered by the eventual redundancies resulting from the transfer of ownership. 
The private management was given to AM InvestCo Italy S.r.l. (Arcelor Mittal), and the contract envisaged the purchase of the business entity of the societies in extraordinary administration by AM InvestCo Italy S.r.l following a period of rental. During this period, the payment was established of a yearly rental charge set at EUR 180 million to be deducted from the transfer price, and whose amount will be determined via a contract in an amount equal to the corrected clearing price (increasing or decreasing) in relation to the evaluation of the stock, of the debts, and of the credits at the end of the leasing period.

The projects of AM InvestCo, which can act under the shield of immunity from prosecution, initially established with the D.L. 1/2015 for the safeguarding of special commissioners and later extended to the successful tenderer with the D.L. 98/2016, include EUR 2.3 billion of investments for the years 2018-2023. Of these, 1.2 billion were reserved for the industry and 1.1 billion, for environmental interventions, including the coverage of mining parks, as well as 8 billion tons of production, with the reabsorption of 10,700 work units.

In April 2019, when the Decreto Crescita D.L. 34/2019 ("Growth Decree") was issued, all the stakeholders involved, especially local ones, entered into conflict, and soon arrived the first threats of withdrawal by ArcelorMittal, which caused central public authorities to momentarily retrace their steps. In fact, with the Salva Ilva decree (D.L. 101/2019), dated August 2019, the provision related to the penal shield was reintroduced, even if with some adjustments and limitations tied to the implementation of the timetable.

This provision was subsequently eliminated in November upon the conversion of the Decree-Law (128/2019). This was met with the decision by ArcelorMittal's management to officially withdraw from the contract.

To justify its position, ArcelorMittal added a second element, that is, the measures issued by the Taranto Criminal Court that "compel ILVA's special commissioners to meet certain requirements by the 13th of December 2019" - a deadline considered impossible to meet by the commissioners themselves-lest the shutdown of furnace n. 2, subjected to seizure since 2012, should commence. These requirements should fairly and prudentially be applied to the other two furnaces of Taranto's plant, but this would it make impossible for the company to fulfil its industrial plan, to manage the plant, and, in general, to fulfil the contract.

This was followed by the reaction of the special commissioners, who, having deemed the decision to terminate the rental contract as malicious, brought an action with the aim of stopping ArcelorMittal's withdrawal, and the subsequent disengagement from the plant and the staff employed.

The dispute between the "private management" and governmental authorities, which came out of the situations related to the penal shield and the use of blast furnace n. 2, resulted in a period of confusion that is still ongoing, during which attempts for conciliation have alternated with suggestions of publicizing the plant. Recently, both parties signed an agreement that has put an end to the legal battle started in November 2019, which, in redesigning the terms of the industrial and financial plan of the factory, has actually postponed until November the final decision on the possible changes in the assets of the governance bodies. In particular, the agreement signed in the first days of March 2020 provides for the fulfilment of the activities envisaged by AIA ("Integrated Environmental Authorization"), that is, the "complete makeover of blast furnace n. 5", and the division of the investments needed for the adjustment of blast furnaces n. 1, 2 and 4 into equal shares between ArcelorMittal and the state. The agreement envisages the use of direct-reduced iron together with other investments in new technologies "with a lower environmental impact", "with the perspective of progressive decarbonization" [40]. The key aspect of the new industrial plan is the construction of a plant for the direct reduction of ferrous minerals (DRI), which will be financed and managed by third-party stakeholders, and of an electric arc furnace, which will be built by AM InvestCo. At full capacity, the scheduled technical arrangements should guarantee a production capacity of around 8 million tons, that is, double the current production, with the subsequent possibility of keeping the initially agreed employment levels. 
The agreement also envisages ArcelorMittal's possibility of withdrawing from the contract by 31 December 2020, paying a fine of EUR 500 million, provided the government fails to sign the "investment agreement" by November 30th, with which it will undertake investment in AM InvestCo's assets to finance the completion of the agreed activities.

In the face of these uncertainties, of the questionable economic viability of the investment, of the hostilities of society and the local authorities, and of the judiciary's pressures, ArcelorMittal may consider it more profitable to leave ILVA, paying the fine provided for in the contract, which would be the cheapest loss to sustain in this scenario.

\section{Discussion and Results}

The case study is of particular interest under the three sustainability dimensions of the triple bottom line approach (environmental, social and economic spheres), which feature strong conflicts between each dimension in all the periods analysed.

In each period, the level of pollution and the relevant health problems and consequent diseases (environmental dimension) conflicted with the rights of the workers to preserve their jobs (social dimension) and with economic value and adequate remuneration for the investments (economic dimension).

Indeed, even if according to the TISM model, sustained economic growth and shareholder value have a direct influence on each other and shareholder value has an indirect link with the human rights of employees and with the standard of living of nearby neighbourhoods, the analysis carried out on the data collected shows that in each period, there is one or more conflicts between the six factors from each section of the triple bottom line, as evidenced in Table 2 and explained below.

Table 2. Triple bottom line in ILVA in the 4 phases.

\begin{tabular}{|c|c|c|c|c|}
\hline Code. & PUBLIC PERIOD & $\begin{array}{l}\text { PRIVATE } \\
\text { PERIOD }\end{array}$ & $\begin{array}{l}\text { RECEIVERSHIP } \\
\text { PERIOD }\end{array}$ & $\begin{array}{c}\text { ARCELORMITTAL } \\
\text { PERIOD }\end{array}$ \\
\hline S1 & $\begin{array}{c}\text { Development of } \\
\text { the steelworking } \\
\text { sector }\end{array}$ & $\begin{array}{c}\text { Loss of } \\
\text { competitiveness }\end{array}$ & $\begin{array}{l}\text { Direct intervention } \\
\text { from the state }\end{array}$ & $\begin{array}{c}\text { Restoration of } \\
\text { competitiveness }\end{array}$ \\
\hline S2 & Creation of value & $\begin{array}{l}\text { Increase in profits } \\
\text { through reduction } \\
\text { of the costs }\end{array}$ & $\begin{array}{l}\text { Degradation of the } \\
\text { plant }\end{array}$ & $\begin{array}{l}\text { Industrial plan } \\
\text { with aim of } \\
\text { breaking even }\end{array}$ \\
\hline S3 & $\begin{array}{l}\text { Improvement of } \\
\text { life conditions }\end{array}$ & $\begin{array}{l}\text { Negative } \\
\text { externalities for } \\
\text { local economy }\end{array}$ & $\begin{array}{l}\text { Increase in } \\
\text { mortality rate } \\
\text { connected to } \\
\text { pollution }\end{array}$ & $\begin{array}{l}\text { Investments for the } \\
\text { safeguarding of } \\
\text { neighbouring } \\
\text { territories }\end{array}$ \\
\hline S4 & $\begin{array}{l}\text { Modernization of } \\
\text { infrastructures }\end{array}$ & $\begin{array}{l}\text { Reduction of } \\
\text { labour costs }\end{array}$ & $\begin{array}{l}\text { Production, even if } \\
\text { with environmental } \\
\text { and health damage }\end{array}$ & End of layoffs \\
\hline S5 & $\begin{array}{c}\text { Acceptance by } \\
\text { local communities }\end{array}$ & $\begin{array}{l}\text { High degree of } \\
\text { biodiversity loss }\end{array}$ & Social pressures & $\begin{array}{l}\text { Covering of } \\
\text { mineral parks }\end{array}$ \\
\hline S6 & $\begin{array}{l}\text { Increase in } \\
\text { pollution }\end{array}$ & $\begin{array}{l}\text { Reduction in } \\
\text { infrastructural } \\
\text { investments }\end{array}$ & $\begin{array}{l}\text { Environmental } \\
\text { disaster }\end{array}$ & $\begin{array}{l}\text { Adjustment of } \\
\text { infrastructures }\end{array}$ \\
\hline
\end{tabular}

\subsection{The "Public" Period-The Compromise of Sustainable Development}

With the birth of metalworking, we assisted, besides the huge development of ancillary activities (S1) and the creation of value (S2), a social transformation of Taranto's territory, which translated into the alteration of the pre-existing structures related to traditional manufacturing sectors and has led to a process of modernization (S4) and to an improvement in the local standard of living (S3). This has entailed some radical changes in the urban structure of the city, so much so that large working-class neighbourhoods have emerged close to the factory, and the municipal boundaries have incorporated smaller neighbouring urban centres (Corriere della Sera, 15 October 1988). 
In this phase, however, environmental factors have been overlooked both by the public world and by the citizens, who have demonstrated a sort of social acceptance (S5) (Corriere della Sera, 22 July 1990; Corriere della Sera, 20 December 1990) of the negative effects of production on the environment (S6) (incidentally, during that time in history, the environmental aspect was not yet considered in its relevance).

\subsection{Privatization-The End of the Compromise}

At the moment of transferring the plant to the Riva industrial group, despite the emergence of environmental issues related to the production plant included in the transaction, the public governance did not mention them in the deed that sanctioned the privatization of the factory. These problems later broke out in full force in the following years, because of the new management's orientation, purely aimed at profit, at the expense of safety and environment [37,41].

Indeed, with the takeover of private management, the "great illusion" of development and the relationship of trust between the factory and the city irremediably cracked (Corriere della Sera, 24 March 1993; Corriere della Sera, 12 August 1993) under the push of the new strategic direction of the private governance, and of the state authorities' difficulty in assuming a reference role in the composition of the interests in the field (Corriere della Sera, 27 June 1994).

In particular, Riva Group's corporate philosophy materialized in the re-thinking of its production strategy from the perspective of pursuing cost-effectiveness, which can be achieved with the reduction of personnel costs (S4) and of costs related to investments in the technical structure. From such conduct, which, in the short-medium term, led to an increase in profits (S2), two fundamental consequences emerged: on one hand, the toughening of public opinion towards the factory following the worsening socio-economic conditions, which made unacceptable and unsustainable the cost of pollution and health damage (S3), and on the other, the worsening production quality, which contributed to making Italian steel less competitive (S1), at the expense of national growth [42]. The sum of these situations, together with the inability of the public institutions to intervene with regulation mechanisms to promote the creation of a new broadened governance philosophy that could create new balances that could comply with the changing contexts, inevitably condemned the firm to decline, with subsequent social, environmental and economic fallout on a national level (S6).

The production drive, given the lack of fundamental investments in technologies and in the context of the production costs related to raw materials and a competent workforce being cut, drained the firm of any future prospects of continuity from a sustainable perspective.

In this sense, previous studies [43] argued that if the plant would have used the best available technologies, the negative impact on the environment and health could have been significantly reduced.

The economic significance of the plant in this period is clear: the plant has been estimated to have contributed 75\% of Taranto's GDP in 2008 [43]. On the other hand, the environmental problems caused by emissions from the plant also translate into a negative economic impact on other sectors of the local economy (S5).

Notably, authorities have repeatedly ordered cows and sheep owned by local farmers to be slaughtered, because the level of dioxins found in their milk or meat exceeded the allowed levels (Repubblica, 27 January 2015); certain types of farming have been prohibited in certain areas (Press release Apulian Region of 25 July 2011).

In this situation, the application of the TISM model, adopted for the analysis of the present case study, would suggest, as a driving factor for sustainability, supportive government policies for sustainability. Action of the government to promote sustainability would have reduced the existing conflict between the factors analysed.

On the contrary, the lack of control by the political actor marks the failure of the market mechanisms in realizing a model of private regulation that could compose, on its own, the complex articulation of the opposing forces represented by the interests converging into the environmental suprasystem. Indeed, the economic actor in the case of ILVA does not act as one of the players in the context system, which, 
in the pursuit of balance and regulatory compromise from a perspective of broadened governance, participates with the others in the process of stabilization between the economic, environmental and social spheres and thus in making the economic interest inherent to the existence of the plant compatible with the conflicting interests of the local community. It follows that job-related problems and environment-related problems merge with the economic ones in a combination of non-compliances, dark sides, stretches and a total lack of long-term integrated policies and adequate measures, both on a central government level and on a local administration one, which makes the negative externalities generated from the factory unsustainable [44].

The transfer from public to private management, characterized by the political strategy of non-interference, has put a stop to the compromise between the social, environmental and economical dimensions of the local and national context, thus bringing forth the defensive reactions of the local community against the plant's ownership, which has become responsible for social and environmental damage, as well as the economic unsustainability of the production on a national and local levels.

The defensive reaction has manifested itself both from governmental institutions and from the foundations represented by the local community, who, after a decade of private governance domination and a lack of regulatory mechanisms set by well-aimed economic policies, has put in place actions for the safeguarding of health and the environment, which are no longer to be bargained with the economic remuneration of local citizens.

Since then, the situation of the steel and iron giant irreversibly plunged, setting off a series of opposing chain reactions between the judiciary and national governmental institutions. The latter were interested in saving the biggest steel plant in Europe, with the perspective of the superior national interest in economic growth in mind. Public governance, therefore, having failed with the regulation mechanisms, adopted an intervention policy of an authoritative type aimed at defining the disputes by resorting to the legal instrument. This is a solution that, on one hand, aims at guaranteeing the immediate survival of the plant considering only the economic perspective; on the other, it risks compromising its future sustainability, since it is dictated by a situation of contingency and not by thoroughly reasoned integrated economic policies designed to achieve socio-economic and environmental sustainability for the production.

\subsection{Post-Privatization}

The need to guarantee production continuity from the perspective of national interest and of the preservation of the already-low local employment levels, thus, has induced the public governance to intervene directly in the management of the firm (S1), first in the form of receivership (from May 2013 to January 2015) and later through special administration (from January 2015 onwards), waiting for the call for tender that was issued on 5th of January 2016, following the authorization for the execution of the release program for the ILVA business entity prepared by the commissioner body, to be concluded by June 2016.

In the ILVA case, the introduced legal provisions intervened by modifying the pre-existing reference standard contained in the D.L. n. 347/2003 with the aim of making the bankruptcy proceedings a public rescue tool characterized by the breadth of the powers conferred to the public authorities in taking measures designed to safeguard the superior national economic interest of the steel and iron business production, and to protect the environment, health and employment.

From this perspective, in the ILVA case, we could speak of a total replacement of the entrepreneurial type, since the visible hand of the state has intervened in the ownership and in the powers typical of the private entrepreneur for the exercise of all the powers previously accruing to the company bodies, which, at least temporarily, lose their function. In this context, the supervisory authorities have thus coincided with the supervised subjects, with consequent distortions in the management and monitoring dynamics.

Indeed, the emergency decree extended and intensified the administrative functions of governmental authorities, and guaranteed the broadest powers to the special commissioners nominated 
for ILVA, also notwithstanding the discipline proper to the current bankruptcy proceedings, as well as to criminal law, causing a "substitution" beyond the limits proper to the norm, to the public governance, and to the private property in the management of the firm [45].

Despite the constant calls to order from the European Commission, and the condemnation from the Court of Justice and from the European Court of Human Rights, as well as the results of countless expert reports that have confirmed the severe pollution produced by the plant and its impact on the increased mortality rate (S3) and morbidity of the population inhabiting the areas close to the factory, governmental authorities have always given to the factory, considered strategically important for national interests, the possibility to continue production, establishing a "lifeline" with the Salva Ilva decrees [46].

The provision contained in art. 3 of the D.L. 92/2015 is emblematic; justified by the goal of guaranteeing the necessary balance between the need for continuing the production activities, of safeguarding employment, of maintaining safety in the workplace, and of health and the environment, it does not stop the exercise of business activity in the factories considered of national strategic interest, despite the seizure order issued in 2012 by Taranto's judiciary for damage to health and the environment. This provision is very much at odds with the goals it was issued for because it justifies the use of the plants that were impounded for causing an environmental disaster (S6) with the declared intent of protecting health and the environment. In fact, implemented in the Italian legal system is the possibility for a company of national strategic interest to continue its activities, even when such activities could exacerbate or prolong the consequences of a crime, so much so that the Constitutional Court has declared its unconstitutionality with the judgement $n$ 58/2018 [47]. In fact, this clearly demonstrates how sustainable development and respect for legitimate human rights regarding health and the environment (S4) seem to lose importance in the face of the economic logic of the market that guides the public governance in perpetual contrast with the judiciary, always present in the history of the firm.

In this "impasse", in which the clash between the diverging social and environmental interests and the economic national needs has reached its peak (S5), the Italian state intervenes in its new role of "last resort regulator" [48], with the task of governing production trajectories and untying the complex knot around the social and societal risks.

It should be observed how, since 2012 and during the whole receivership and special administration periods, there have been many different changes in strategy by the governments that have alternated and sometimes even within the same government. This has led to the loss both of precious years, during which it may have been necessary to realize some major structural interventions aimed at environmental rehabilitation and at the economic-productive revitalisation of the firm, and of national wealth connected to the decreasing GDP and to the significant state funds invested to keep alive an industrial complex considered strategic for the whole national economic system.

In particular, it has been estimated that in years between 2013 and 2017, there was a loss of GDP attributable to the deterioration in production of the ILVA steel plant (S2) equal to EUR sixteen billion, to which must be added the loss in gross fixed capital formation, equal to another EUR 3.7 billion [49]. In this situation, it seems clear that not even one of the triple bottom line dimensions has been successfully pursued (all the factors are underlined in red).

\subsection{The ArcelorMittal Period}

After a series of compromises with the social parts, ArcelorMittal's plan, left alone following Marcegaglia's departure (advocated by the European antitrust authority, even if not satisfactory from an environmental and social point of view), seems, at least on paper, promising from an economic-productive perspective since it is designed to take back Taranto's steel plant to breakeven production (S2), hoped by the government to restore competitiveness on an international level (S1).

However, the "ArcelorMittal" chapter opened the door to another phase of uncertainty in the choices made by the public governance, always tighter between the diverging forces of the local population torn by the choice between health and jobs, of the pressures by the community authorities 
in the environmental and "state aid" fields, and of the national interest in the economic production of the factory. Moreover, with the change of government, the balances between the interests of the parts were redesigned, and the tug of war between the public authorities and private governance fluctuates in a continuous state of becoming actions and reactions that risk determining a final debacle for the plant. In particular, the issue that triggered the crisis between public authorities, private management and territory resides in —at least, apparently—the privilege of immunity from prosecution enjoyed by the purchaser in accordance with the provisions contained in the aforementioned D.L. 98/2016. The newly installed government, in an attempt to rebalance the interests in the field in favour of the local community's human rights, seeks to take it down.

The period under scrutiny sees a program on the basis of the contract that was discussed in Section 5.3, which should include engagement in environmental rehabilitation (such as the covering of the mining quarries already implemented-S5 — and adjustment of the facilities—S6), guaranteeing the employment level (S4) and the recovery of competitiveness. However, the legal and strategic issues that were discussed in Section 5.3 may not meet these expectations and show insuperable problems in the pursuit of contractual commitments.

Following what the TISM model suggests, a return to public management in the governance of the plant would be desirable, and it should take charge of all the unsolved issues after years of absence and uncertain policies.

In the analysis of the panorama of events, in fact, it can be observed how even with the new private management, the ILVA case confirmed an unstable and asymmetrical model of relations among the actors, based on the dominance of the large company over public institutions, which, after the fundamental error of putting the plant in the hands of foreign stakeholders with little interest, have proved to be weak and inattentive, especially in the local and national dimensions, leading to a fragmented and forgotten local community.

The lack of an industrial policy matured from knowledge and awareness of the context, as well as from adequate attention and public governance's closeness to the interests to be mediated, has produced uncertainty and weakness for the actions put in place. With these premises, the public authorities who have taken turns over the years could not be able to understand how to face the ILVA question, wallowing in the Hamlet-like doubt in choosing whether to return to public governance interventionism in inspiration and market regulation, while the judiciary, environmental pressures and concerns, and inadequate management destroyed the factory and the local community.

In fact, within what could be defined as the "never-ending story" of the ILVA case, the conflicting interests and the difficult balance of the rights to protect, of national and local relevance, are yet alive and unsolved, with severe costs and losses for the population, and resemble the same issues of those a century ago: economic production and health protection.

\section{Conclusions}

The possibilities of modern states to pursue paths to development in the long run presuppose the composition, in dynamic terms, of the many different instances, often opposing each other, of environmental, economic and social characters that manifest and require both public and private governance to put in place the right strategies and regulatory actions.

It is about a systemic and complex sense of balance that cannot be solved with a call to standardized intervention paradigms, but that requires governances to have an ability to understand and adapt to local, national and international emerging dynamics. This does not mean that in this "game of forces" that arises on the paths of economic growth, all of those instances are fully satisfied, but that this balance results in the government's action's capacity to make this combination of interests compatible with the economic dimension of development, and to make this acceptable for all the players involved. This compromise, which is based on a well-balanced cost-benefit allocation, is thus at the foundation of the regulations towards which market mechanisms should strive, with the support of governmental 
authorities, which, in turn, should balance the intervention measures in the economy, so as to solve the eventual conflict of interest and direct the system towards trajectories of growth.

The role of public institutions and the effects produced by the governance mechanisms adopted in the ILVA case were investigated through a comparison between the different historical periods and by shifting the focus between the different aspects of sustainable development (economic, environmental and social) using the triple bottom line approach and the information and available data through the TISM model.

Severe critical issues emerged in each of the analysed phases, attributable first to the lack of strong government action and then to the lack of a conscious industrial policy able to define goals and rules.

Whenever governmental authorities move away from the system of interests represented by the enterprise and end up acting in a fragmentary, contradictory and contingent way, only guided by the emergent situation, we assist the failure of the market and of regulation attempts, with the subsequent collapse of economic activity and distancing from the paths of overall growth and development over time.

In particular, evidence shows how, in the absence of stable, coherent, strong and present public institutions, capable of reading the forces of the local and international context and of intervening with regulatory actions inspired by a planned and interiorized economic strategy, the market, left in the hands of the private entrepreneur only, is destined to fail, and the paths of multidimensional sustainable development stray away from the ambitions of modern states.

Thus, regardless of the outcome that the ArcelorMittal chapter may have in the ILVA case, from the historical readings of the events, it is evident how the methodological vacuum demonstrated by the public institutions is a consequence of the lack of a planned strategy, of a background culture, and of a comprehensive and far-sighted view.

It follows that the actions put in place in the absence of an awareness of the context and of well-structured, stable and shared economic-political guidelines take on the character of an emergency intervention, marked by the condition of breathless contingency and by a situation of weakness compared to private contractual strength and to the pressures exercised by the system of interests gravitating around the steel plant.

This evidence could be fundamental for policy makers to understand and apply the right strategy and regulation in order to compose the different instances and to follow and achieve sustainable development, above all, in the Agenda 2030 era.

The limitation of this work mostly resides in the fact that the methodology used was based on an interpretative approach and on the application of a model, albeit one well-established in the literature. Future research may focus on only one of the periods subject to discussion, hopefully the last, focusing attention with a structured content analysis on the elements that characterize the composition of the different interests as well as on the relations maintained with the various stakeholders. Another interesting and future line of research could be the study of the impacts on SDGs (Agenda 2030) of the ILVA now and in future years.

Author Contributions: All authors wrote the paper, but their primary individual contributions are reflected as follows: Sections 1, 3 and 5 are ascribed to R.L.; Sections 2, 4 and 6 are ascribed to M.T. All authors have read and agreed to the published version of the manuscript.

Funding: This research received no external funding.

Conflicts of Interest: The authors declare no conflict of interest.

\section{References}

1. United Nations. Transforming Our World: The Agenda 2030 for Sustainable Development; United Nations: New York, NY, USA, 2015.

2. Villiers, C.; Dumay, J.; Maroun, W. Qualitative accounting research: Dispelling myths and developing a new research agenda. Account. Financ. 2019, 59, 1459-1487. [CrossRef] 
3. Qu, S.Q.; Dumay, J. The qualitative research interview. Qual. Res. Account. Manag. 2011, 8, $238-264$. [CrossRef]

4. Dumay, J.; Rooney, J. “Measuring for managing?” An IC practice case study. J. Intellect. Cap. 2011, 12, 344-355. [CrossRef]

5. Yin, R.K. Case study methods. In APA Handbook of Research Methods in Psychology, Vol 2: Research Designs: Quantitative, Qualitative, Neuropsychological, and Biological; American Psychological Association: Washington, DC, USA, 2012; pp. 141-155.

6. European Parliament. The ILVA Industrial Site in Taranto. Resource Document. Directorate General 683 for Internal Policies; European Parliament: Bruxelles, Belgium, 2015.

7. Mill, J. A few words on non-intervention. Nonscientific Magazines and Newspapers, 1859; Foreign Polcy Perspective n.8.

8. Pigou, A.C. The Economics of Welfare; Macmillan: London, UK, 1920.

9. Sidgwick, H. The Principles of Political Economy; Edizioni Bizzarri: Roma, Italia, 1887.

10. Keynes, J.M. The General Theory of Employment, Interest, and Money; UTET: Torino, Italy, 1936.

11. Lerner, A.P. The Economics of Control: Principles of Welfare Economics; MacMillan: London, UK, 1944.

12. Borgonovi, E.; Fattore, G.; Longo, F. Management Delle Istituzioni Pubbliche; Egea: Milano, Italy, 2009.

13. Ogus, A. Regulation: Legal Form and Economic Theory; Hart Publisher: Oxford, UK, 1994.

14. Boyer, R. The Regulation School: A Critical Introduction; Columbia University Press: New York, NY, USA, 1990; ISBN 0231065485.

15. Coriat, B. Technical Flexibility and Mass Production: Flexible Specialisation and Dynamic Flexibility. In Industrial Change and Regional Development; Belhaven Press: London, UK, 1991.

16. Goddard, A. Reform as regulation-Accounting, governance and accountability in UK local government. J. Account. Organ. Chang. 2005, 1, 27-44. [CrossRef]

17. Glaeser, E.; Shleifer, A. The Rise of the Regulatory State. J. Econ. Liter. 2003, 41, 401-425. [CrossRef]

18. Hudson, R. Producing Places; The Guilford Press: London, UK, 2001.

19. Bridge, G. The social regulation of resource access and environmental impact: Production, nature and contradiction in the US copper industry. Geoforum 2000, 31, 237-256. [CrossRef]

20. Gibbs, D. Integrating sustainable development and economic restructuring: A role for regulation theory? Geoforum 1996, 27, 1-10. [CrossRef]

21. O'Connor, J. Natural Causes: Essays in Ecological Marxism; The Guilford Press: New York, NY, USA, 1998.

22. Zamagni, S. Democrazia economica e libertà nelle società di mercato: Una prospettiva dalla moderna teoria economica. Il Politico 1994, 170, 389-404.

23. Daly, H.E. Beyond Growth: The Economics of Sustainable Development; Beacon Press: Boston, MA, USA, 1996.

24. Hahn, R.; Kühnen, M. Determinants of sustainability reporting: A review of results, trends, theory, and opportunities in an expanding field of research. J. Clean. Prod. 2013, 59, 5-21. [CrossRef]

25. Anbarasan, P. Sushil Stakeholder Engagement in Sustainable Enterprise: Evolving a Conceptual Framework, and a Case Study of ITC. Bus. Strateg. Environ. 2018, 27, 282-299. [CrossRef]

26. Sushil Modified ISM/TISM process with simultaneous transitivity checks for reducing direct pair comparisons. Glob. J. Flex. Syst. Manag. 2017, 18, 331-351. [CrossRef]

27. Sushil Interpretive Matrix: A Tool to Aid Interpretation of Management and Social Research. Glob. J. Flex. Syst. Manag. 2005, 6, 27-30.

28. Lai, A.; Panfilo, S.; Stacchezzini, R. The governmentality of corporate (un)sustainability: The case of the ILVA steel plant in Taranto (Italy). J. Manag. Gov. 2019, 23, 67-109. [CrossRef]

29. de Villiers, C.; Dumay, J. Construction of research articles in the leading interdisciplinary accounting journals. Accounting Audit. Account. J. 2013, 26, 876-910. [CrossRef]

30. Affinito, M.; De Cecco, M.; Dringoli, A. Le privatizzazioni Nell'Industria Manifatturiera Italiana; Donzelli: Roma, Italy, 2000.

31. Amatori, F. Storia Dell'IRI. Il Miracolo Economico e il Ruolo Dell'IRI; Laterza: Bari-Roma, Italy, 2013.

32. Balconi, M. La siderurgia italiana (1945-1990); Il Mulino: Bologna, Italy, 1991.

33. Bonel, M. Siderurgia e Sviluppo Economico: Il Caso del Centro Siderurgico di Taranto, in Annesi, M., 657 Barucci, P. e Dell'Angelo G.G. (a cura di), Studi in Onore di Pasquale Saraceno; Giuffrè: Milan, Italy, 1975.

34. Pa, D. L'acciaieria più grande d'Europa. Sole 24 Ore, 18 July 2012. 
35. Leone, E. "Siderurgia meridionale", in D'Antone, L. (a cura di), 701 dell'intervento straordinario nel Mezzogiorno (Taormina, 18-19 novembre 1994), Associazione 702 Nazionale per gli interessi del Mezzogiorno d'Italia, Roma. In Radici Storiche ed Esperienza Dell'Intervento Straordinario nel Mezzogiorno; Bibliopolis: Napoli, Italy, 1996.

36. Schachter, G. Politiche Alternative di Sviluppo per il Mezzogiorno; Annesi, M., Barucci, P., Dell'Angelo, G.G., Eds.; e 724 (a cura di), Studi in onore di Pasquale Saraceno; Giuffrè: Milano, Italy, 1975.

37. Ranieri, R.; Romeo, S. La Siderurgia IRI dal Piano Sinigaglia alla Privatizzazione in Russolillo F. (a 720 cura di), Storia dell'Iri. Un Gruppo singolare. Settori, Bilanci, Presenza Nell'Economia Italiana; Editori 721 Laterza: Roma-Bari, Italy, 2014.

38. Rinella, A. Oltre L'acciaio. Taranto Problemi e Progetti; Progredit: Bari, Italy, 2002; p. 87.

39. Morelli, A. Il decreto ILVA: Un drammatico bilanciamento tra principi costituzionali. Dirit. Penal. Contemp. 2013.

40. Palmiotti, D. Ex Ilva, perdite record da oltre 100 milioni al mese. Sole 24 Ore, 21 May 2020.

41. Giannì, R.; Migliaccio, A. Taranto oltre la crisi. Meridiana. 2016, 85, 155-180.

42. De Cecco, M. Pochi investimenti, zero qualità: Così i Riva hanno ucciso l'ILVA. La Repubb, 3 June 2013.

43. Tonelli, F.; Short, S.W.; Taticchi, P. Case study of ILVA, Italy: The impact of failing to consider sustainability as a driver of business model evolution. In Proceedings of the Global Conference on Sustainable Manufacturing, Berlin, Germany, 23-25 September 2013.

44. FIDH (International Federation of Human Rights). The Environmental Disaster and Human Rights Violations of the ILVA Steel Plant in Italy; FIDH: Paris, France, 2018.

45. Ferroni, M. I profili pubblicistici dell'amministrazione straordinaria delle grandi imprese ed il caso ILVA. Federalismi 2019, 4, 1-25.

46. Bucci, G. L'Ilva come laboratorio di uno Stato neo-corporativo tra conflitti di potere e disastri socio-ambientali. In La Nuova Dimensione Istituzionale dei Processi 666 Economico-Sociali; Cacucci Editore: Bari, Italy, 2015.

47. Cavaliere, S. Il caso ILVA, l'interesse economico nazionale e la sua compatibilità con la dignità dei lavoratori e dei cittadini nella sentenza n. 58/2018 della Corte costituzionale. Dirit. Pubblico Eur. 2019, 1, 64-80.

48. Gouldson, A.; Bebbington, J. Corporations and the Governance of Environmental Risk. Environ. Plan. C Gov. Policy 2007, 25, 4-20. [CrossRef]

49. Bricco, P. La crisi dell'ILVA costa 16 miliardi. Sole 24 Ore, 7 December 2017. 